\title{
RELATIONSHIP BETWEEN APOPTOTIC-LIKE CHANGES IN STORED BOAR SEMEN AND DNA FRAGMENTATION IN PREIMPLANTATION EMBRYOS*
}

\author{
Magdalena Bryła, Monika Trzcińska \\ Department of Animal Reproduction Biotechnology, National Research Institute of Animal \\ Production, 32-083 Balice n. Kraków, Poland \\ Corresponding author: mbryla@izoo.krakow.pl
}

\begin{abstract}
The aim of this experiment was to study the relationship between apoptotic-like changes in spermatozoa and DNA fragmentation in embryos obtained after insemination with fresh and stored semen. The ejaculates collected from three boars (five ejaculates from the same boar) were extended in Biosolwens Plus extender and stored for five days at $15-17^{\circ} \mathrm{C}$. Semen, both fresh (Day 0) and stored (Day 5) used for insemination was analysed to detect apoptotic-like changes using fluorescence method: an assay to assess early changes in the membrane integrity of the sperm using the YO-PRO-1 fluorophore. After 5.5 days of insemination embryos were flushed out of the uterus and DNA fragmentation using TUNEL was analysed. In the fresh semen an average of 2.7, 3.7 and $6.2 \%$ of apoptotic sperm was observed in boar nos. 1, 2 and 3, respectively. After five days of storage the percentage of apoptotic sperm significantly increased up to $8.0,15.7$ and $23.2 \%$ in each analysed boar. The TUNEL index was $7.1 \%$ in the morphologically normal expanded blastocysts obtained after insemination with stored semen, and approximately $1.7 \%$ after insemination with fresh semen. A greater number of degenerated embryos and higher incidence of DNA fragmentation in the morphologically normal blastocysts were observed after insemination with stored semen which consists of higher percentage of apoptotic sperm compared to results from insemination with fresh semen.
\end{abstract}

Key words: boar, sperm, apoptosis, embryos, TUNEL

Artificial insemination (AI) with extended liquid boar semen is extensively used in pig reproduction. Extended liquid boar semen is often used within the same day of production, but may be stored at a temperature of $15^{\circ} \mathrm{C}$ for up to 5 days before AI.

The application of artificial insemination resulted in a search for the most convenient methods for evaluation of semen quality. Standard semen parameters such as percentage of motile and morphologically normal spermatozoa is not sufficient for prediction of fertilizing capacity of sperm. Therefore, new methods are still needed to make the evaluation of sperm more reliable. Recent studies have demonstrated that

\footnotetext{
*This study was financed from statutory activity, project no. 02-5.02.1 (3428.1).
} 
detection of apoptotic-like changes in ejaculated sperm may be a new criterion for evaluating semen quality (Chen et al., 2006; Anzar et al., 2002). Apoptosis is characterized by specific ultrastructural features. During the early phases of apoptosis the cytoplasmic membrane becomes slightly permeant. Certain dyes, such as the green fluorescent YO-PRO-1 dye can enter apoptotic cells, whereas other dyes, such as the red fluorescent dye, propidium iodide (PI), cannot. Thus, use of YO-PRO-1 dye and PI together provides a sensitive indicator for apoptosis (Trzcińska et al., 2009).

Research performed to date has indicated that the presence of apoptotic spermatozoa in fresh semen could contribute to poor fertility in breeding bulls (Anzar et al., 2002). Previous research has also suggested that apoptotic sperm appears to be a cause of male infertility in humans (Marchetti et al., 2002) and may be responsible for the deaths of human embryos in the early stages of development (Evenson, 1999). Our previous studies (Trzcińska et al., 2011) indicated the after insemination with stored boar semen, which contains a higher percentage of apoptotic sperm than fresh semen, a significantly higher number of degenerated embryos was obtained. Moreover, the analysis of the morphologically normal embryos based on the average number of nuclei did not differ significantly between embryos obtained after insemination with fresh and stored semen.

An important parameter for mammalian embryo quality is the assessment of blastomere fragmentation as well as the number of cells (Mateusen et al., 2005; Szułdrzyńska and Smorąg, 1980). It has been suggested that DNA fragmentation indicating cell death is a common feature of the development of mammalian embryos (Pomar et al., 2005). The parameters by which apoptosis in embryos can be established include nuclear fragmentation, identifiable with dyes that specifically bind to DNA such as 4,6-diamidino 2-phenylindole (DAPI) and the presence of single- and double-strand DNA breaks detected by terminal dUTP nick and labelling (TUNEL) (Pomar et al., 2005). Deoxynucleotidyl transferase (TdT) catalyses the incorporation of biotinylated deoxyuridine at the sites of the DNA breaks. The signal is amplified by avidinperoxidase, enabling detection by fluorescent microscopy (Neuber et al., 2002). Positive signals for these biochemical markers were detected in at least one nucleus of every in vivo and in vitro blastocyst from many mammalian species, including pigs (Long et al., 1998; Hao et al., 2003; Pomar et al., 2005; Mateusen et al., 2005; Bryła et al., 2009). This data indicates that nuclear fragmentation occurred during normal embryo development. A high cell count at any given time and a concurrent low degree of fragmentation indicate good embryo quality and a higher chance for successful development and implantation.

The objective of our present study was to examine the influence of storing spermatozoa preserved over five days on quality of embryos based on DNA fragmentation.

\section{Material and methods}

\section{Experimental animals}

Three boars, crossbreds of the Polish Landrace and Large White breeds (21.3 \pm 0.9 months old; weight: $239.7 \pm 6.5 \mathrm{~kg})$, were used in this study. Boars were 
housed in individual pens in environmentally controlled buildings. Their feed was provided twice daily and water was available ad libitum. The boars were of proven fertility.

Gilts that are crossbreds of the Polish Landrace and Polish Large White breeds (7.4 \pm 0.8 months old; weight: $97.4 \pm 4.7 \mathrm{~kg}$ ) were used as embryo donors in this study. Donor gilts were housed in buildings under stable conditions, provided commercial food and given access to water ad libitum.

All animals were kept at the Experimental Station in Żerniki Wielkie in Poland. All animal experiments were approved by the Local Ethics Board for Animal Experiments in Kraków (Poland).

\section{Semen collection and preparation}

Ejaculates were collected weekly, by the gloved-hand method, from three boars (five ejaculates per boar). Whole ejaculates were collected by hand manipulation into water-jacketed vessels. After separation from the gel, the semen was filtered through gauze. Sperm volume, concentration, and motility were estimated immediately after collection. Sperm concentration was measured using a hemocytometer. To evaluate motility, 1-mL samples were taken, placed in a water bath at $37^{\circ} \mathrm{C}$, and evaluated after 30 min under a phase-contrast optical microscope (200x magnification). For evaluating sperm morphology, an extended semen smear stained with Eosin-Nigrosin (Sigma-Aldrich Chemie Gmbh Steinheim, Germany) was made and observed at 1000x magnification under immersion oil using phase-contrast microscopy. Deformities in head shape, tail formation, and cytoplasmic droplets qualified spermatozoa as abnormal. Semen samples were diluted to a final concentration of $2.5 \times 109$ sperm per dose $(80 \mathrm{ml})$ in the Biosolwens Plus (Biochefa, Sosnowiec, Poland) extender, after which they were placed in cold storage at $15-17^{\circ} \mathrm{C}$ for five days. Assessment of sperm motility was repeated every day of liquid preservation of semen. Samples of semen were incubated for $30 \mathrm{~min}$. The percentage of motile spermatozoa was then evaluated under a phase-contrast optical microscope $(200 \mathrm{x}$ magnification) equipped with a heated plate at $37^{\circ} \mathrm{C}$.

\section{Fluorescent staining to assess sperm viability using YO-PRO-1/PI assay}

Fluorescence analysis was performed on the first and fifth day of semen storage. The Vybrant Apoptosis Assay Kit \#4 (Molecular Probes Inc., Eugene, USA) was used to detect changes in plasma membrane permeability to YO-PRO-1 related to apoptosis (Idziorek et al., 1995; Martin et al., 2004). A total of $2 \times 10^{6}$ sperm cells were diluted in $1 \mathrm{ml}$ phosphate buffered saline (PBS, Sigma-Aldrich Chemie Gmbh, Steinheim, Germany), and $1 \mu \mathrm{l}$ of YO-PRO-1 (100 $\mu \mathrm{mol} / \mathrm{l})$ was added. The tubes were gently mixed and incubated for $20 \mathrm{~min}$ at room temperature after which 2 $\mu \mathrm{mol} / \mathrm{l}$ PI was added to each tube. After the incubation period, the sperm cell suspensions were analysed under a fluorescence microscope at 400x magnification. At least 200 spermatozoa per sample were evaluated using appropriate filters for red (PI) and green (YO-PRO-1) fluorescence detection. The fluorescent signals were measured by microscopic observation in at least 200 cells/sample per slide in one field by one observer. 


\section{Production and collection of in vivo embryos}

The donor gilts were made to superovulate by the injection of 1500 IU PMSG (Serogonadotropin, Biowet, Poland) and 1000 IU of hCG (Choluron, Biomed, Poland), which was administered $72 \mathrm{~h}$ later. At the onset of estrus, $24 \mathrm{~h}$ after hCG administration, the gilts were artificially inseminated twice, at 12-hour intervals, with a standard dose of semen. Seventy-five superovulated donor gilts were inseminated with fresh semen ( 5 gilts per group for each of 3 boars) and seventy-five donors were inseminated with stored semen at Day 5 of preservation. Immediately after stunning and bleeding the gilts (approximately $168 \mathrm{~h}$ after hCG injection), the uteri were removed and flushed with Dulbecco's PBS (Invitrogen ${ }^{\circledR}$, Carlsbad, CA, USA) for embryo collection. Morphological analyses of embryos were performed within 20 minutes of collection. After morphological evaluation the embryos were detected for DNA fragmentation.

\section{Morphological classification of blastocysts}

Blastocysts were classified on the basis of their morphological appearance using a stereomicroscope. Blastocysts that were symmetrical and spherical, with a clear inner cell mass, intact trophectoderm, and no visible extruded blastomeres were categorized as having a normal morphology.

\section{Detection of DNA fragmentation by TUNEL method}

DNA fragmentation of expanded blastocysts was analysed by using a combined technique based on simultaneous nuclear staining and TUNEL using a modification of the procedures by Brison and Schultz (1997).

For the preparation of TUNEL, embryos were fixed for $1 \mathrm{~h}$ at room temperature in 4\% paraformaldehyde in PBS (Sigma-Aldrich Chemie Gmbh, Steinheim, Germany). The embryos were washed three times in $50 \mu$ d drops of PBS-PVP $(1 \mu \mathrm{g} / \mathrm{ml}$ polyvinylpyrrolidone in PBS, Sigma-Aldrich Chemie Gmbh, Steinheim, Germany), then permeabilized in a humidified box with $0.1 \%$ Triton X-100 in PBS (SigmaAldrich Chemie Gmbh, Steinheim, Germany) for $30 \mathrm{~min}$, at the room temperature, and finally washed in drops of PBS-PVP solution. The embryos were incubated in fluorescein-conjugated dUTP and TdT (TUNEL reagent; In Situ Cell Detection kit, Roche Diagnostics, Germany) for $1 \mathrm{~h}$ at $38.5^{\circ} \mathrm{C}$ and $5 \% \mathrm{CO}_{2}$ in air. As a positive control, one or two embryos per TUNEL analysis were incubated in $50 \mathrm{U} / \mathrm{ml}$ DNase I (Roche Diagnostics, Germany) for $20 \mathrm{~min}$, at $38.5^{\circ} \mathrm{C}$. As a negative control, one or two embryos per TUNEL analysis were incubated in fluorescein-dUTP in the absence of TdT. After the reaction, the embryos were washed three times in drops of PBS-PVP solution and transferred through a gradient of Vecta-Shield with DAPI (Vector Laboratories, Burlingame, CA, USA) at 75\% and 100\% (v/v) in PBS-PVP and mounted on a glass slide. Labelled nuclei were examined under a Nikon Eclipse E600 microscope fitted with epifluorescent illumination. The total number of nuclei per blastocyst (determined by nuclear staining with DAPI) and the number of nuclei positive for TUNEL labelling (TUNEL-positive nuclei) were counted (nuclei were recorded as positive for TUNEL when they had visible green fluorescence cells with DNA strand breaks and condensed nuclei). The DNA-fragmented nucleus index 
(TUNEL index) was calculated by dividing the number of TUNEL-positive cells by the total number of cells per embryo.

\section{Statistical analysis}

The results are expressed as the means \pm S.D. Statistical analyses were performed using the Statistica 6.0 program (StatSoft, Tulsa, USA). The effect of the mean values obtained for particular parameters was estimated by Duncan's multiple range test. The statistical differences were considered to be significant at $\mathrm{P}<0.01$ and $\mathrm{P}<0.05$. The relationships between the analysed parameters were determined based on Spearman's correlations.

\section{Results}

Our results showed that the mean volume of ejaculates from three boars ranged from 292.0 to $302.4 \mathrm{ml}$, and the mean concentration $\left(1 \times 10^{6}\right.$ spermatozoa $\left./ \mathrm{mL}\right)$ of ejaculates ranged from $286.0 \pm 19.6$ to $321.0 \pm 21.2$. No significant differences in semen volume and concentration were found among the analysed ejaculates. The microscopic estimations of motility of fresh semen of boar nos. 1, 2 and 3, as expressed by the percentage of motile spermatozoa, ranged from $76.7 \pm 2.9$ to $80.0 \pm 5.0$. As semen storage time increased the percentage of motile spermatozoa decreased. In all analysed ejaculates significant differences in motility were observed between fresh and stored semen used for artificial insemination (Table 1).

Table 1. Motility of fresh and stored semen

\begin{tabular}{l|c|c|c}
\hline \multirow{2}{*}{ Day of storage } & \multicolumn{3}{|c}{ Motility (\%) } \\
\cline { 2 - 4 } & $\begin{array}{c}\text { boar no. } \\
(\mathrm{n}=5)\end{array}$ & $\begin{array}{c}\text { boar no. } 2 \\
(\mathrm{n}=5)\end{array}$ & $\begin{array}{c}\text { boar no. 3 } \\
(\mathrm{n}=5)\end{array}$ \\
\hline Fresh semen & $80.0 \pm 5.0$ & $78.3 \pm 7.6$ & $76.7 \pm 2.9$ \\
Day 1 & $78.3 \pm 7.6$ & $76.7 \pm 5.8$ & $73.3 \pm 5.8$ \\
Day 2 & $70.0 \pm 4.8$ & $68.3 \pm 7.6$ & $66.7 \pm 5.8$ \\
Day 3 & $66.7 \pm 5.8$ & $55.0 \pm 8.7$ & $51.7 \pm 2.9$ \\
Day 4 & $53.3 \pm 5.8$ & $46.7 \pm 5.7$ & $48.3 \pm 2.9$ \\
Day 5 & $53.3 \pm 7.6^{* * *}$ & $43.3 \pm 5.8 * * *$ & $41.7 \pm 2.9 * * *$ \\
\hline
\end{tabular}

*** Significant differences in motility between fresh semen compared with stored semen (Day 5 of storage).

Both fresh and stored semen (Day 5 of storage) was analysed to assess the early changes in sperm membrane integrity using YO-PRO-1/PI. The analysis of this fluorophore identified three spermatozoa populations: live sperm with intact membranes (YO-PRO-1- /PI-), apoptotic sperm positive for YO-PRO-1 and negative for PI (YO-PRO-1+/PI-), and necrotic sperm positive for PI (YO-PRO-1+/PI+). A 
significant increase in the percentage of apoptotic sperm analysed on Day 0 compared with that analysed on Day 5, was observed in semen from all analysed boars (Table 2). A decrease in the percentage of live sperm and an increase in the percentage of necrotic sperm was observed between fresh semen (Day 0) compared with stored semen (Day 5) for all analysed semen. The quality of fresh semen from boar no. 1, based on the percentage of live sperm, was the highest of all of the boars, whereas the fresh semen of boar no. 3 contained the lowest percentage of live sperm $(77.1 \pm 3.3)$ and the highest percentage of apoptotic (6.2 \pm 2.2$)$ and necrotic sperm (16.7 \pm 5.9$)$, compared with the other boars. The YO-PRO-1/PI analysis revealed that the percentage of apoptotic sperm (YO-PRO-1+/PI-) correlated with the percentage of motile spermatozoa $(\mathrm{r}=-0.819 ; \mathrm{P}<0.0001)$.

Table 2. The percentage (mean $\pm \mathrm{SD}$ ) of apoptotic (YO-PRO1+/P-), necrotic (YO-PRO-1+/PI+), live (YO-PRO-1- /PI-) sperm stained with YO-PRO-1/PI in three boars used for insemination ( 5 ejaculates/boar)

\begin{tabular}{|c|c|c|c|c|}
\hline \multirow{2}{*}{$\begin{array}{l}\text { Subpopulation } \\
\text { of sperm }\end{array}$} & \multirow{2}{*}{$\begin{array}{c}\text { Day } \\
\text { of storage }\end{array}$} & \multicolumn{3}{|c|}{ Boar } \\
\hline & & no. $1(\mathrm{n}=5)$ & no. $2(n=5)$ & no. $3(n=5)$ \\
\hline \multirow{2}{*}{$\begin{array}{l}\text { Apoptotic } \\
\text { (YO-PRO1+/PI-) }\end{array}$} & Fresh semen & $2.7 \pm 1.7$ & $3.7 \pm 1.2$ & $6.2 \pm 2.2$ \\
\hline & Day 5 & $8.0 \pm 0.8 \mathrm{~A}, * * *$ & $15.7 \pm 3.3 \mathrm{~B}, * * *$ & $23.2 \pm 2.4 \mathrm{C}, * * *$ \\
\hline \multirow{2}{*}{$\begin{array}{l}\text { Necrotic } \\
(\mathrm{YO}-\mathrm{PRO} 1+/ \mathrm{PI}+)\end{array}$} & Fresh semen & $4.7 \pm 1.7 \mathrm{~A}, \mathrm{a}$ & $9.8 \pm 3.5 \mathrm{~b}$ & 16.7 $\pm 5.9 \mathrm{~B}, \mathrm{c}$ \\
\hline & Day 5 & $27.2 \pm 1.5 \mathrm{a}$ & $37.2 \pm 2.7 \mathrm{~b}$ & $33.3 \pm 6.3 \mathrm{a}, \mathrm{b}$ \\
\hline \multirow{2}{*}{$\begin{array}{l}\text { Live } \\
\text { (YO-PRO-1- /PI-) }\end{array}$} & Fresh semen & $92.6 \pm 3.2 \mathrm{~A}$ & $86.5 \pm 2.8 \mathrm{~A}$ & $77.1 \pm 3.3 \mathrm{~B}$ \\
\hline & Day 5 & $64.8 \pm 1.6 \mathrm{~A}$ & $47.1 \pm 6.6 \mathrm{~B}$ & $43.5 \pm 7.5 \mathrm{~B}$ \\
\hline
\end{tabular}

\footnotetext{
A, B - means with different superscripts in the row differ significantly at $\mathrm{P}<0.01$.

a, b, $\mathrm{c}-$ means with different superscripts in the row differ significantly at $\mathrm{P}<0.05$.

$* * *(\mathrm{P}<0.01)$ significant increase in percentage of apoptotic sperm between fresh semen compared with stored semen (Day 5).
}

In the present study both fresh and stored semen was used for insemination and fertilizing capacity of semen was verified based on number of successfully inseminated gilts and was determined based on the number of cells and incidence of DNA fragmentation in the embryos obtained after insemination with that semen. Our studies indicated no significant differences in the effectiveness of insemination with fresh $(88.9 \%)$ and stored $(81.5 \%)$ semen from all three boars. The number of normal embryos obtained for all animals inseminated with fresh or stored semen was 15.8 and 10.1, respectively. Significant differences were observed in the number of normal and degenerated embryos obtained after insemination with fresh and stored semen from all boars $(\mathrm{P}<0.01)$ (Table 3$)$. Our results revealed that after insemination with stored semen a significantly greater number of degenerated embryos was observed compared to fresh semen and the lowest number of degenerated embryos was obtained after insemination with stored semen from boar no. 1. This may have resulted in the fact that stored semen from boar no. 1 had significantly lower percentage of apoptotic sperm compared with stored semen from boar nos. 2 and $3(\mathrm{P}<0.01)$. 


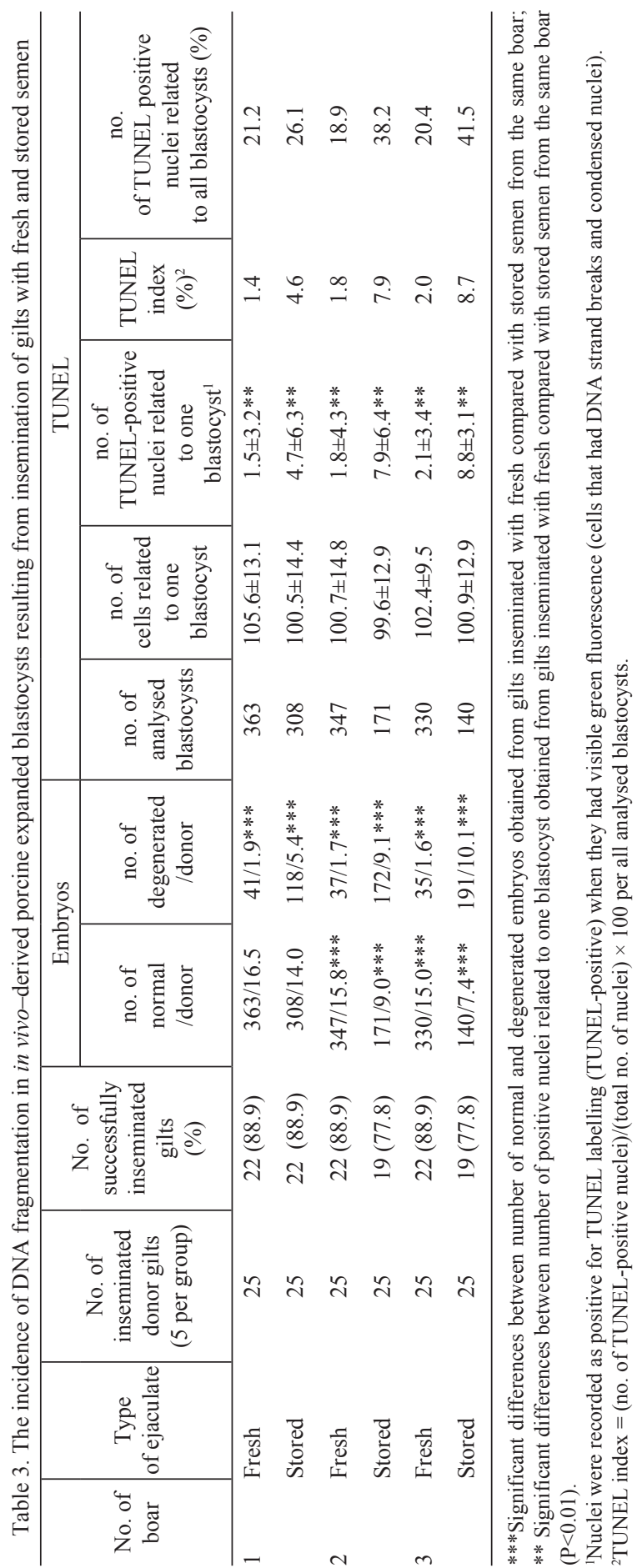


The study showed that the total number of nuclei in the in vivo-derived expanded blastocysts was negatively correlated with the number of TUNEL-positive nuclei $(\mathrm{r}=-0.686 ; \mathrm{P}<0.0001)$ and the TUNEL index $(\mathrm{r}=-0.661 ; \mathrm{P}<0.0001)$, whereas the number of TUNEL-positive nuclei was positively correlated with the TUNEL index $(\mathrm{r}=0.989 ; \mathrm{P}<0.0001)$ (data not tabulated).

\section{Discussion}

Recent studies demonstrated that the presence of apoptotic spermatozoa in semen doses could be one of the reasons for poor fertility (Taylor et al., 2004; Said et al., 2006; Anzar et al., 2002) and may be responsible for the deaths of human embryos in the early stages of development (Evenson, 1999). Moreover, these results are similar to our previous observations (Trzcińska et al., 2011), in which we found that after insemination with stored semen which contains a higher percentage of apoptotic sperm than fresh semen, a significantly higher number of degenerated embryos was obtained. Moreover, the embryos derived from stored semen have similar quality in terms of morphology and total number of cells per embryo than those derived from fresh semen.

In this study, the assessment of embryo quality was determined from the number of cells, and TUNEL-positive nuclei. Basal levels of TUNEL-positive nuclei in the embryo may be important in the developmental processes by selectively removing cells from the inner cell mass that have retained trophoectodermal competence (Gjørret et al., 2003). Our results showed as our previous study, no significant differences in the average number of cell/blastocysts between embryos obtained from gilts inseminated with fresh compared with stored semen. Therefore, the number of TUNEL-positive nuclei/blastocysts obtained per animal inseminated with fresh and stored semen differed significantly. This observation is most pronounced in results of insemination with semen from boar no. 3. The stored semen of this boar was characterized by the lowest percentage of live and the highest percentage of apoptotic spermatozoa compared with semen from other boars. Our study revealed that the embryos obtained after insemination with this stored semen had the highest incidence of DNA fragmentation compared with embryos derived after insemination with fresh semen. Therefore, almost $80 \%$ and $75 \%$ of all expanded blastocysts derived from gilts inseminated with fresh and stored boar semen, respectively, showed no DNA fragmentation.

In conclusion, the morphologically normal embryos derived from stored semen have a higher incidence of DNA fragmentation per embryo than those derived from fresh semen. Moreover, in agreement with our previous study, after insemination with stored semen a significantly greater number of degenerated embryos was observed. 


\section{References}

Anzar M., Liwei H., Buhr M.M., Kroets ch T.G., Pauls K.P. (2002). Sperm apoptosis in fresh and cryopreserved bull semen detected by flow cytometry and its relationship with fertility. Biol. Reprod., 66: 354-360.

Bris on D.R., Schultz R.M. (1997). Apoptosis during mouse blastocyst formation: evidence for a role for survival factors including transforming growth factor. Biol. Reprod., 56: 1088-1096.

B ryła M., Trzcińs k a M., W i e c z or e k J. (2009). Analysis of in vivo- and in vitro-derived pig expanded blastocysts based on DNA fragmentation. Anim. Sci. Pap. Rep., 27: 59-68.

Chen Z., Hau ser R., Trbovich A.M., Shifren J.L., Dorer D.J., Godfrey-B ailey L., $\mathrm{S}$ in $\mathrm{g}$ h N.P. (2006). The relationship between human semen characteristics and sperm apoptosis: a pilot study. J. Androl., 27: 112-120.

Even s o n D.P. (1999). Flow cytometry assays of male fertility. Method. Cell Biol., 33: 401-410.

Gjørret J.O., Knijn H.M., Dieleman S.J., Avery B., Larsson L-I., Maddox-Hyt tel P. (2003). Chronology of apoptosis in bovine embryos produced in vivo and in vitro. Biol. Reprod., 69: 1193-1200.

H a o Y., L a i L., M a J., I m G.S., B on k A., Prather R.S. (2003). Apoptosis and in vitro development of preimplantation porcine embryos derived in vitro or by nuclear transfer. Biol. Reprod., 69: 501-507.

Idziorek T., Estaquier J., De B els F., A meisen J.C. (1995). YOPRO-1 permits cytofluorometric analysis of programmed cell death (apoptosis) without interfering with cell viability. J. Immunol. Methods, 185: 249-258.

L ong C.R., D obrins ky J.R., Garrett W.M., J o hn s on L.A. (1998). Dual labelling of the cytoskeleton and DNA strand breaks in porcine embryos produced in vivo and in vitro. Mol. Reprod. Dev., 51: 59-65.

Marchett i C., Obert G., Deffosez A., Formstecher P., Marchetti P. (2002). Study of mitochondrial membrane potential, reactive oxygen species, DNA fragmentation and cell viability by flow cytometry in human sperm. Hum. Reprod., 17: 1257-1265.

M a r t in G., S a b i d o O., D u r a n d P., L e v y R. (2004). Cryopreservation induces an apoptosis-like mechanism in bull sperm. Biol. Reprod., 71: 28-37.

Mateusen B., Van Soom A., Maes D.G., Donnay I., Duchateau L., Lequarre A.S. (2005). Porcine embryo development and fragmentation and their relation to apoptotic markers: a cinematographic and confocal laser scanning microscopic study. Reproduction, 129: 443-452.

Neuber E., Luetjens C.M., Chan A.W., S chatten G.P. (2002). Analysis of DNA fragmentation of in vitro cultured bovine blastocysts using TUNEL. Theriogenology, 57: 2193-2202.

P o m a r R.F.J., T e erds K.J., Kidson A., Colenbrander B., Tharas ant T., Aguilar B., R o e le n B.A.J. (2005). Differences in the incidence of apoptosis between in vivo and in vitro produced blastocysts of farm animal species: a comparative study. Theriogenology, 63: 2254-2268.

Said T., Agarwal A., Grunewald S., Rasch M., Baumann T., Kriegel C., Li L., G lander H.J., Th o m a s A.J. Jr, P a a c h U. (2006). Selection of nonapoptotic spermatozoa as a new tool for enhancing assisted reproduction outcomes: an in vitro model. Biol. Reprod., 74: $530-537$.

S zułdrzyńs ka J., S morąg Z. (1980). Morphology and rate of in vitro development of mouse embryos frozen in liquid nitrogen (in Polish). Rocz. Nauk. Zoot., 7: 19-30.

T a y 1 or S.L., W e n g S.L., F o x P., D u r a n E.H., M or s h e di M.S., O e hn ing er S., B e e b e S.J. (2004). Somatic cell apoptosis markers and pathways in human ejaculated sperm: potential utility as indicators of sperm quality. Mol. Hum. Reprod., 10: 825-834.

Trzcińska M., Bryła M., B ochenek M., Słomski R., S morąg Z. (2009). Assessment of plasma membrane and chromatin structure of sperm from transgenic and non-transgenic boars. Theriogenology, 72: 1141-1147.

Trzcińska M., B ryła M., S morąg Z. (2011). Apoptotic-like changes in the spermatozoa of fresh and stored boar semen and the quality of embryos produced in vivo. Anim. Reprod. Sci., 124: 90-97. 


\section{MAGDALENA BRYŁA, MONIKA TRZCIŃSKA}

\section{Zależność pomiędzy zmianami apoptotycznymi w przechowywanym nasieniu knura a stopniem fragmentacji DNA w przedimplantacyjnych zarodkach}

\section{STRESZCZENIE}

Celem pracy było określenie związku pomiędzy zmianami apoptotycznymi w plemnikach knura a jakością zarodków na podstawie fragmentacji DNA uzyskanych po inseminacji nasieniem świeżym i przechowywanym. Badanie przeprowadzono na nasieniu trzech knurów po 5 ejakulatów od każdego knura. Nasienie po pobraniu rozcieńczano w rozrzedzalniku Biosolvens Plus i przechowywano przez 5 dni w temp. $15-17^{\circ} \mathrm{C}$. Zarówno nasienie świeże, jak i w piątym dniu przechowywania oceniano w kierunku wczesnych zmian apoptotycznych przy użyciu fluorochromu YO-PRO-1 i użyto do inseminacji dawczyń zarodków. Zarodki uzyskane poprzez przepłukanie rogów macicy po 5,5 dnia od inseminacji oceniano na podstawie fragmentacji DNA z zastosowaniem metody TUNEL. W nasieniu świeżym wykazano średnio 2,$7 ; 3,7$ oraz $6,2 \%$ plemników apoptotycznych, odpowiednio dla knura nr 1, 2 i 3, natomiast w nasieniu przechowywanym przez 5 dni zaobserwowano istotny wzrost odsetka plemników apoptotycznych: 8,0; 15, 7 i 23,2\%, odpowiednio dla poszczególnych knurów. Wykazano wzrost wielkość indeksu apoptotycznego w prawidłowych morfologicznie zarodkach uzyskanych po inseminacji nasieniem przechowywanym, w porównaniu z uzyskanym po inseminacji nasieniem świeżym (odpowiednio 7,1; 1,7\%). Po inseminacji nasieniem przechowywanym o wyższym odsetku plemników apoptotycznych, w porównaniu z nasieniem świeżym uzyskano wyższy odsetek zarodków zdegenerowanych, jak również rozpoznano wyższą liczbę komórek z fragmentacją DNA w zarodkach prawidłowych morfologicznie. 